\begin{tabular}{ll}
\hline \hline MINING AND METALLURGY INSTITUTE BOR & ISSN: 2334-8836 (Štampano izdanje) \\
UDK: 622 & ISSN: 2406-1395 (Online) \\
\hline \hline
\end{tabular}

\title{
DETERMINATION THE NECESSARY STRENGHT OF STOPE FILLINGS AT TOTAL LAYER EXCAVATION**
}

\begin{abstract}
The basic aims of layer excavation by filling methods are: increasing or total layer spending without ore impoverishment, layer excavation in complex mining and geological conditions, environmental factors preservation, improvement of ergonomic and safety work conditions and recirculation the waste material.

For achievement of these aims, it is necessary to put in the stope the filling material of appropriate physical and mechanical characteristics, especially the pressure strength. This work presents a discussion of procedure of filling material selection with necessary strength, and application of filling stoping methods at complete layer excavation and protection of the earth surface and objects on it from damages.
\end{abstract}

Keywords: total excavation, filling of the stopes, stoping strength

\section{INTRODUCTION}

Complete excavation of the mineral ore layer without depletion of mineral ore and with preservation the environmental faction in the exploitation field can be only realized by the mining method with filling the cavities in ascending or descending order of excavation and filling [1]. Depending on the objectives of full deposit excavation with filling the cavities, the required strength of backfill can be determined and selection the type of filling material with which that the strength can be achieved [2].
This can be achieved by applying of solidifying backfill [3].

Completely obtaining of layers without getting ore dilution can be carried by the following groups of excavation methods [4]:

1. The central excavation of corridors, steep ore veins and lenses is a) from bottom to top, standing of equipment on the back fill, b) from top to bottom, under backfill, when the equipment is at a solid rock (ore).

2. Single-or multi-layer excavation of powerful ore deposits; a) vertically layered

\footnotetext{
* University of Belgrade, Technical Faculty Bor, Vojske Jugoslavije 12, 19210, Bor, Serbia, e-mail address: jsokolovic@tf.bor.ac.rs

** This paper presents the results of the Projects TR 33007, "Implementation of Modern TechnicalTechnological and Environmental Solutions in the Existing Production Systems of the Copper Mine Bor and Copper Mine Majdanpek" and TR 33038 "Improving Technology of Exploitation and Processing of Copper Ore with Monitoring the Living and Working Environment in the RTB Bor Group", funded by Ministry of Education, Science and Technological Development of the Republic of Serbia. The authors are grateful to the Ministry for financial support
} 
excavation from bottom to top (equipment moves on the backfill), b) horizontal layered excavation from top to bottom and beneath concrete slab (equipment is moving on solid ground).

3. Sublevel excavation of ore deposits with subsequent excavation back filling; a) curing over burden with movement of the excavation front from bottom to top, b) under concrete slabs, by excavation back filling with curing over burden (excavation fronts are moving from top to bottom.

4. Chamber pillar ore deposits excavation with ore storage, filling of stope by solidifying backfill and subsequent obtaining the protective ore pillars in filling by the same stoping method. It can be applied as: a) panel and b) cross-excavation of chambers.

Depending on the order of mining, construction and excavation geometry, objectives, implementation costs of excavation methods, physical and mechanical characteristics of the deposit and associated rocks, as well as the depth of the deposit, the necessary strength of backfill will be determined.

\section{RELATIONS BETWEEN ASSOCIATED DEPOSITS ROCKS AND FILLED EXCAVATED AREAS IN THE DEPOSIT}

Strength of solidifying backfill is satisfactory (normative) if it is possible to secure the opening of the artificial, (backfilling) massive of designed mining areas and excavation, and if the earth's surface and objects above the deposits can be maintained from deformation. The gravitational and tectonic (static) and blasting (dynamic) powers have effect on massive from backfilling material. Mass of backfilled excavation may be subjected to deformation under pressure, stretching, shearing, bending in uniaxial, biaxial and volume of stressed state. Strength of filling material shall be selected to suit the strength of the uniaxial pressure For choice and control the necessary strength of filling materials considering the role to be met, regardless of the character of the load. The required strength of filling material is determined by one or more factors:

a) stability (holding) of vertical open sides,

b) horizontally open ceilings,

c) the allowable deformation of the earth's surface,

d) the ability to move of equipment on the backfill surface, etc.

Mass from the filling material and surrounding rocks, in certain circumstances, form a complex spatial system backfill-rock. The main structural elements of such system roof and floor rocks and filling space are very different.

Calculation of strength of backfill is based on the knowledge of the stressdeformation characteristics of natural and artificial rock, (from backfill), mass in the excavation area, character of their interaction and is reduced to solution of three tasks.

1. Finding a load to the mass of backfilled excavation,

2. Determination of stresses in the backfill as an integral element of the system of rocks (rocks backfilled area),

3. Determining the necessary strength of backfill, resulting in the required ratio of manifestation (safety) for a given stress state, with the impact of other technological factors in the excavation of deposits.

Load to an artificially massive backfill of excavation depends on: the physical-mechanical characteristics of surrounding rocks, stress in them, backfilled excavation geometry, (size, depth and slope) and physicalmechanical characteristics of backfill, as well as the role of construction of backfilling materials fulfill during the further exploitation and termination of deposit exploitation.

In total deposit excavation (excavation by prior filling), the roof of deposit, near the excavation area, forms a zone of reduced pressure (loading), and in mineral massif in front of the zone of advancement 
occurs a zone of high support pressure, Fig. 1 With the increase in width of excavated space and backfilled space, the roofing rocks and backfill in the space filled, behave like the surrounding rocks and permissive support units, until backfill receives the entire burden of roofing rocks pillar. Load on the excavation comes from roofing rock slab, which is partly supported on the backfilled part of excavation area, and partially on the ore massif. Dimensions of unloading zones are proportional to the deformation characteristics of the backfill, $\varepsilon$. Deformation characteristics of backfill depend on the type of backfill and installation. At $\varepsilon \leq 3 \%$ moving of leaning rocks is performed by folding without cracking and fragmentation. At $\varepsilon \geq 3 \%$ in the roof occurs cracking and layering of rocks. The value of stress concentration coefficient in the ore massif is determined by the width of excavated space $\mathrm{L}$ and the stress concentration in the ore massif, by the formula:

$$
\begin{aligned}
& \mathrm{K}_{\mathrm{k}}=2.1-1.1 e^{-(L / 80)^{1 . .5}} \\
& \mathrm{~K}_{\mathrm{k}}=\left(0.8 \mathrm{l}_{\mathrm{e}} \cdot \mathrm{n}+14\right) \mathrm{H}^{-0.33}
\end{aligned}
$$

where:

e - base of natural logarithm

$\mathrm{L}$ - width of excavated space $\mathrm{m}, \mathrm{L}=\mathrm{n} \cdot \mathrm{l}_{\mathrm{e}}$

$1_{e}$ - excavation width (tape, layer) in getting (the equivalent pillar width of the excavation ceiling)

$\mathrm{n}$ - number of tracks in simultaneous getting to achievement the critical width $\mathrm{l}_{\mathrm{k}}=\mathrm{n} \cdot \mathrm{l}_{\mathrm{e}}$

$\mathrm{H}$ - depth of works for which stresses in the roof are related; $\tau=\rho g \mathrm{H},(\mathrm{Pa})$

Tests have shown that maximum pressure of support at width of excavation space $\mathrm{L}=30-40 \mathrm{~m}$ is $(1.5-1.6) \rho g \mathrm{H}$. Maximum is at $15-20 \mathrm{~m}$ from the forehead of excavation front , and the width of stressed zone is about $50 \mathrm{~m}$. Backfill material suffers loading only at width of excavated space 40 $60 \mathrm{~m}$.
During excavation of backfill below deposits, backfill material plays the role of artificial roofing below which the unloading zone is also formed in the area of excavation and zone of support pressure on the sides in front of excavation forehead and in the backfilled space. The load depends of backfill weight and roofing rocks pressure, if they already have the suffered deformations.

\section{REQUIRED BACKFILL STRENGHT AT CHAMBERS EXCAVATION WITH BACKFILL}

Economical massive excavation of the low-grade (low value) ore deposits applying excavation method with filling the cavities, can only be performed by the use of highly productive excavation methods. The chamber pillar excavation method can be one of them with ore storage, with chamber backfilling after ore discharge by curing backfill and subsequent obtaining of protective pillars of ore using the same stoping method, for which an analysis of required backfill strength have to be carried out (Fig. 2). The required backfill strength can be viewed for three stages where a pillar of backfill material can be found in excavation area.

1. When the chamber is located between the protective pillars from ore (stage I),

2. When the chamber is located between the pillar of ore and the pillar from hardened backfill adjacent to the excavated chamber (stage II) or backfilled space,

3. When the chamber is located between the protective pillars from hardened backfill.

1. In the first stage backfill in the chamber will not be burdened by any vertical load of more lying rocks, except its own mass. Lateral load in the pillar of backfill may occur due to deformations the sides of chamber. The stable range of chamber ceiling $\left(l_{e}\right)$ is determined from strict conditions 
of stability the mine premises and excavation and chamber ceiling. Stability of the undermined ceiling to critical deformation is determined from the condition.

$$
\mathrm{g}_{\mathrm{r}}>\mathrm{g}_{\mathrm{d}}
$$

where:

$\mathrm{g}_{\mathrm{d}}$ - allowable deformation of ceilings at which the ceiling of chamber is stable,

$\mathrm{g}_{\mathrm{r}}$ - relative deformation of chamber ceiling. It is determined by the formula:

$\mathrm{g}_{\mathrm{r}}=1 /\left[1+\left(\mathrm{H}_{\mathrm{R}} / \mathrm{le}\right)^{\mathrm{f}}\right]$

$\mathrm{H}_{\mathrm{R}}$ - reduced for monolithic mass requirements, depth of chamber ceiling

$\mathrm{H}_{\mathrm{R}}=\left(1-\mathrm{K}_{\mathrm{g}}\right) \mathrm{H}_{\mathrm{k}}$

$\mathrm{H}_{\mathrm{k}}$ - thickness of the roofing sediments at the surface to the plane of ceiling chamber.

$\mathrm{K}_{\mathrm{g}}$ - stability loss coefficient of ceiling due to cracking and structural properties of rocks (depend of RQD characteristics). Its value can be determined based on the percentage of the extracted core.

$$
\mathrm{K}_{\mathrm{g}}=0.84+0.01 \mathrm{Nj}-0.0002 \mathrm{Nj}^{2}
$$

where:

$\mathrm{Nj}$ - percentage of extracted core (often showing a high value), f - coefficient of rocks strength by Protogakonov,

$1_{e}$ - equivalent stable range of chamber cavity (width).

Equivalent stable range (width) of chamber can be determined, if adopted boundary conditions, and solved explicitly by the formula $1_{\mathrm{e}}$.

$\mathrm{g}<0.001$ - stable range of chamber,

$\mathrm{g}=(0.001-0.04)-$ state between stability and complete caving in,

$\mathrm{g} \leq 0.04$ - complete collapse of leaning roofing

$$
l_{e}=\sqrt[f]{\frac{g H_{R}^{f}}{1-g}}=H_{R} f \sqrt{\frac{g}{1-g}},(\mathrm{~m})
$$

Stresses will be concentrated in the sides of chamber as shown in Fig. 1.

They will not be transferred to the backfill in the chamber, or more chambers. While undermined cavity beneath the roofing reaches a critical range (talking about the cavity because at excavation filling it will never completely include roofing materials).

$$
\mathrm{l}_{\mathrm{k}}=\mathrm{H}_{\mathrm{k}} \sqrt[f]{\frac{g}{1-g}},(\mathrm{~m}) \text { at } \mathrm{g}>0.04
$$

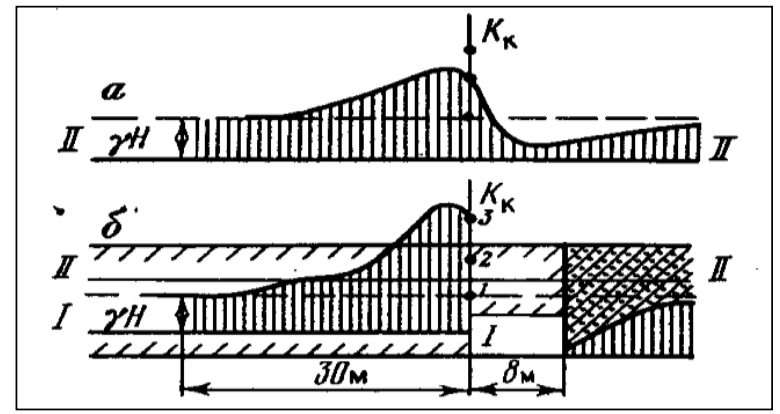

Figure 1 Chart of changes of the stress concentration in the ore and massif of the backfill

2 The second stage of chamber position in the excavation and backfilled space is the most common. The exploitation of large steep ore bodies, critical range of excavated areas where the roof caving occurs, is less than the length of excavation front. Blocks of caved rocks will load the backfilled space if the backfill is compressible (plastic) that will result in larger deformations in the roof, and even to the deformations of the earth's 
surface (in shallower deposits). Yet the filled space represents the relief zone. At the moving of excavation front from the periphery of the ore body to the opening premises, the following cases of stress can be logged:

a) Above the first of excavated chambers at width of excavated space $\mathrm{L}=\mathrm{nl}_{\mathrm{e}}<\mathrm{l}_{\mathrm{k}}$ (stable equivalent widths), the clamping stresses appeared in the excavation roof and the comprehensive stresses are concentrated on the sides of excavation and undisturbed rocks, depending on the width of excavated space. Coefficient of power concentration is determined by formula $\mathrm{K}_{\mathrm{k}}$, and vertical stress in the massif is:

$$
\sigma_{\mathrm{p}}=\mathrm{K}_{\mathrm{k}} \rho_{\mathrm{s}} \mathrm{gH},(\mathrm{Pa})
$$

Horizontal stress $\sigma_{\mathrm{y}}$ on the chamber side according to Fig. 2 is:

$$
\sigma_{y}=\frac{\mu}{1-\mu} K_{k} \rho_{s} g H,(\mathrm{~Pa})
$$

where:

$\mu$ - is the Pauson coefficient $\mu=(0.4 \div 0.6)$ (coefficient of side load).

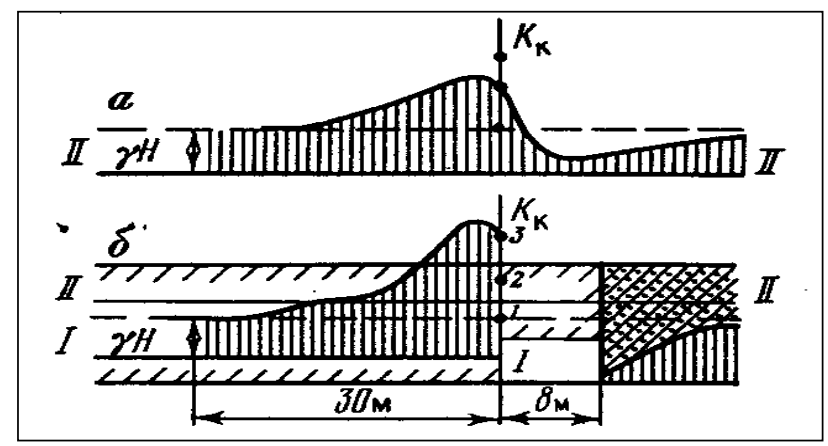

Figure 2 Scheme for calculation the stress of protective pillars on backfill in the chamber

Concentration of stress coefficient as in front of the forehead excavation front in the mine, and as in the final pillars of the backfill will increase with each subsequent excavation chamber, until the range of the excavated space does not exceed the critical width $L>l_{k}$.

b) When it excavated more chambers, so that the range of excavated space $\mathrm{L}$ becomes unstable or crashes, it will cause occurrence vertical stress in the backfill massif. Size of the vertical stress, which can occur in artificial pillars of the backfill, is calculated using the principle of simultaneous deformation of combined supports, pillars of the ores and pillars of backfill by the formula:

$$
\sigma_{1}=\frac{K_{a} \rho_{s} g H S_{k}}{10^{6}\left(S_{z}+0,77 S_{p} \frac{E_{s}}{E_{z}}\right)}+10^{-6} \rho_{z} g h_{z}
$$

where:

$\rho_{\mathrm{s}} ; \rho_{\mathrm{z}}$ - density of rock material and backfill material

$\mathrm{H}$ - depth of excavated ceiling space

$\mathrm{Sk}$; Sz - surface of ore pillars and pillars of the backfill

Es; Ez - deformation modulus of ore deposit and backfill material

$\mathrm{K}_{\mathrm{a}}$ - impact coefficient of the deposit inclination angle to the load of backfill

$\mathrm{K}_{\mathrm{a}}=\cos ^{2} \alpha-\eta \sin ^{2} \alpha ; \eta=\mu /(1-\mu)$

$\mathrm{h}_{\mathrm{z}}$ - height of backfill pillar (height of excavated and backfilled space)

$\alpha$ - deposit inclination angle (slope of filled cavity). 
Strength of backfill in the excavated area must be greater than vertical stress that occurs in the backfill to prevent loosening and compacting of backfill and further deformation of roofing.

$$
\sigma_{\mathrm{z}}>\sigma_{1}
$$

In deep thin deposit, a compacting of backfill may be allowed to a certain height, at which the illicit deformations of the earth's surface will not occur and the reduction of safety coefficient K [4].

c) The final event of the second stage occurs at the movement of excavation front so that the getting of chambers is performed between the massive of ore and massive of backfill. The roof is based on excavated ore front, with console of not supported roofing on backfill of length $1<1 ; 1<\mathrm{n} \cdot 1_{\mathrm{e}}$ and part of the roofing which is caved under more lying masses. Chamber of excavation is located under the console, where the vertical stresses are reduced. Maximum vertical stress is in front of excavation front in ore massif. And in the excavation chamber at a distance $1<l_{k}$ there is a zone of reduced vertical stress. At a distance $\mathrm{L}>\mathrm{l}_{\mathrm{k}}$, the massive and backfill are under concentrated vertical stress, the same as in the ore massif. For finding the necessary strength of backfill to preserve the earth's surface from deformation, it is necessary to take into account the possible allowed backfill compression at which there will be no damage to the earth's surface.

For blind isolated deposits with proper form, influence of size (height) of excavated areas and backfilled area to deformation (settlement) of the earth's surface, depending on the compression properties of backfill, is evaluated based on the safety coefficient whose value should be greater than are permitted by Table 1 [5].

$$
\mathrm{Ks}>\mathrm{Kd}=\mathrm{H} / \Delta \mathrm{P}
$$

The vertical acceptable size of deformation of backfilled space $\Delta \mathrm{P}$ is determined by the formula:

$$
\Delta \mathrm{P}=\varepsilon_{\mathrm{o}} \mathrm{h}_{\mathrm{z}}(1-\mathrm{e}) \sigma_{1} / \sigma_{\mathrm{z}}, \quad(\mathrm{m})
$$

where:

$\Delta \mathrm{P}$ - decrease of height of pillars by backfill under load $\sigma_{1},(\mathrm{~m})$

$\sigma_{1}$ - acting vertical stress, $(\mathrm{Pa})$

$\varepsilon_{0}$ - deformation characteristics of certain type of backfill

$\mathrm{h}_{\mathrm{z}}$ - thickness (height) of backfill pillar

$\sigma_{\mathrm{z}}$ - strength of backfill to the pressure

$\mathrm{K}_{\mathrm{s}}$ - safety coefficient which evaluates the stability of roofing.

The necessary or sufficient strength of backfill $\sigma_{z}$ for thin deep deposits can be calculated from the above formula, where due to roofing load backfill will be overloaded and partially compressed. Permitted backfill compression will be $\Delta \mathrm{P}=\mathrm{H} / \mathrm{Kd}$, and the necessary strength of backfill $\sigma_{\mathrm{z}}$ :

$$
\sigma_{z}=\frac{\sigma_{1} \ln \cdot \varepsilon_{o} h_{z}}{\ln (\Delta P)},(\mathrm{Pa})
$$

3. The stage of performing excavation of protective pillar or chamber which is located between the pillars of hardened protective backfill (in the backfill) is the most dangerous, because the stress concentrations occur in the pillars on both sides from excavated areas. Stresses are added, and can be calculated by equations for $\sigma_{\mathrm{p}}$ and $\sigma_{\mathrm{y}}$. The manifestation of dynamic phenomena and rock bursts can occur in the preparation rooms. Rock bursts will not occur if the rock of pillars is not prone to the accumulation of elastic deformations energy and if concentrated stresses are less than rock hardness to the pressure $\sigma_{\mathrm{p}}<\sigma_{\mathrm{cs}}$.

Rock bursts will not occur if the backfill in filled space has a corresponding compressive strength, so that can perform stiffening of ore pillar and ensure the stability of excavation chamber during the excavation. Normative compressive strength backfill in the process of obtaining of chambers between the pillars of backfill materials shall be as follows:

$$
\sigma_{z}=\frac{\sigma_{s} K_{z}}{K_{f} \cdot K_{o}}
$$


where:

$\sigma_{\mathrm{s}}$ - stress in backfill pillars,

$\sigma_{\mathrm{s}}=\mathrm{K}_{\mathrm{a}} \mathrm{K}_{\mathrm{h} \rho} \mathrm{gH} \cdot \mathrm{L}_{\mathrm{s}} / 10^{6} \mathrm{~L}_{\mathrm{z}}$,

$\mathrm{K}_{\mathrm{z}}$-coefficient of safety $\mathrm{K}_{\mathrm{z}}=(1.5-3)$,
$\mathrm{K}_{\mathrm{f}}$ - coefficient of pillar form (given the influence of shape and dimensions of pillar on supporting ability $\left[K_{\mathrm{f}}=\left(\mathrm{a} / \mathrm{h}_{\mathrm{s}}\right)^{0.5}\right.$ at $\left.\mathrm{a}>\mathrm{h}_{\mathrm{s}}\right]$ or $\left[\mathrm{K}_{\mathrm{f}}=0.6+0.4\right.$ $\mathrm{a} / \mathrm{h}_{\mathrm{s}}$ at $\mathrm{a}>\mathrm{h}_{\mathrm{s}}$;

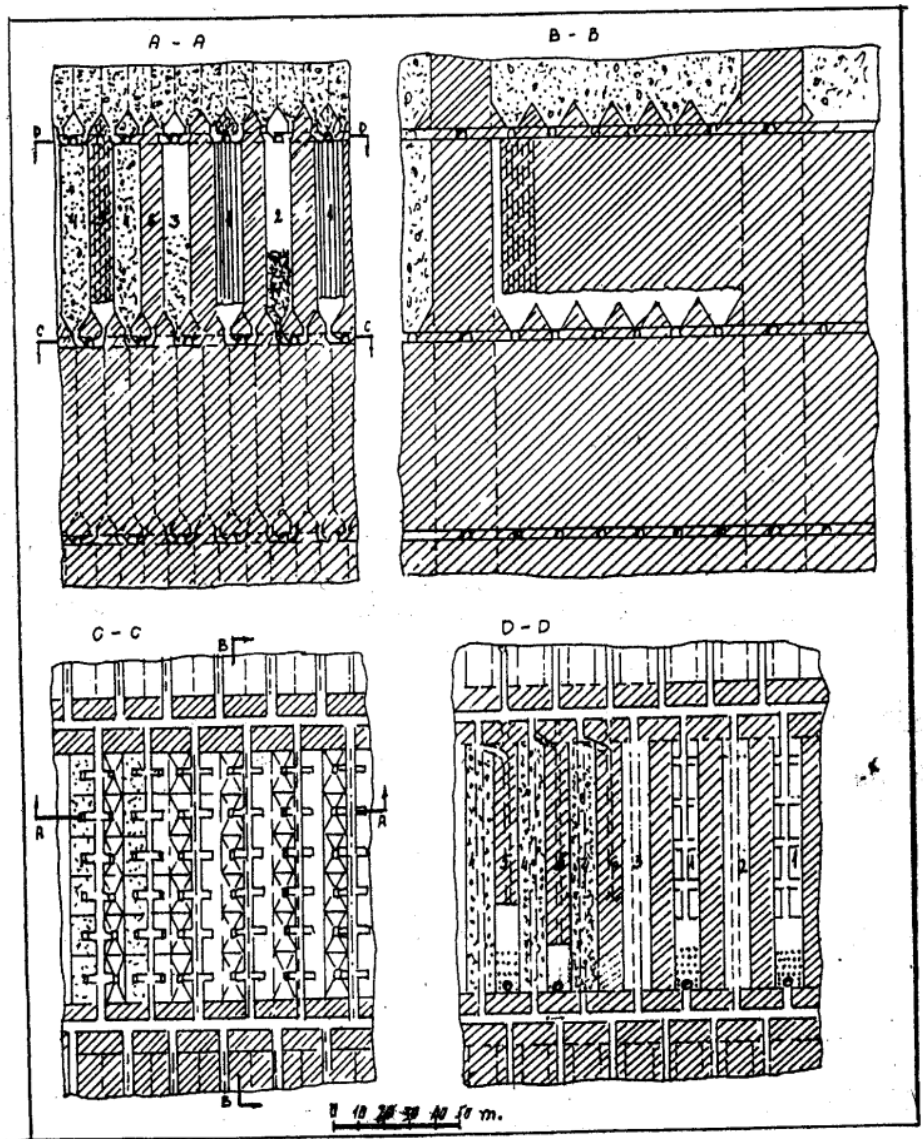

Figure 3 Stoping with backfilling of chambers and subsequent obtaining of columns

Table 1 Safety coefficients

\begin{tabular}{|c|c|c|c|}
\hline \multirow{2}{*}{$\begin{array}{l}\text { Object category } \\
\text { on surface }\end{array}$} & \multirow{2}{*}{$\begin{array}{l}\text { Permitted horizontal } \\
\text { deformations }(\mathbf{m m} / \mathbf{m})\end{array}$} & \multicolumn{2}{|c|}{$K_{d}$ - for layers } \\
\hline & & Ore & Coal \\
\hline I & 2.0 & 150 & 300 \\
\hline II & 3.5 & 100 & 200 \\
\hline III & 5.5 & 50 & 100 \\
\hline
\end{tabular}

a - backfill pillar width,

$\mathrm{h}_{\mathrm{s}}$ - height of the pillar from curing backfill),
$\mathrm{K}_{\mathrm{o}}$ - coefficient that takes into account the increasing of strength pillars at pressure due to compression; $\mathrm{K}_{\mathrm{o}}=\sigma_{\mathrm{k}} / \sigma_{\mathrm{o}}$, 
$\mathrm{H}$ - depth of the upper surface of the pillar,

$\mathrm{K}_{\mathrm{h}}$ - coefficient that takes into account the degree of load of backfill pillar by caved rocks from roofing,

$\mathrm{L}_{\mathrm{p}}$ - width of the panel block (chamber) in the backfill,

$\mathrm{L}_{\mathrm{z}}$ - width of the panel of artificial pillars of backfill.

For the unexplored "in situ" conditions $\mathrm{K}_{\mathrm{h}}=0.5$ and for chambers between the pillars of backfill which are not backfilled $\mathrm{K}_{\mathrm{h}}=\mathrm{L} / \mathrm{h}<1$, where $\mathrm{L}$ - chamber width (undermined pillar).

Strength of backfill materials for ensuring the stability of horizontal rooms respectively, projected span of rooms in the fill is determined by the formula:

$$
\begin{aligned}
\sigma_{\mathrm{e}}= & \mathrm{K}_{\mathrm{z}}\left[0,49 \rho \mathrm{gH}_{\mathrm{z}} \cos \alpha\left(0.95-\mathrm{e}-{ }^{0.06 a}\right)-\right. \\
& 1.76], \mathrm{Pa}
\end{aligned}
$$

Selection of dimensions of chambers and pillars and their arrangement at excavation, strength of backfill of chamber and pillar mining method with storage of ore and subsequent back filling of stopes by curing backfill, if more horizons are dug, should be done by equations $\Delta \mathrm{P}$ and $\sigma_{\mathrm{z}}=\mathrm{f}(\Delta \mathrm{P})$. In them, there will be a change of values $\mathrm{H}_{\mathrm{z}}=\mathrm{Nh}_{\mathrm{H}} ; \mathrm{H}_{\mathrm{z}}$ - height of backfilled space depends on the $\mathrm{N}$ height of excavated horizons $\mathrm{h}_{\mathrm{H}}$. Allowable deformation of backfilling area $\Delta \mathrm{P}^{\prime}=\left(\Delta_{1}+\Delta_{2}+\Delta_{3}\right) \mathrm{N}$ does not depend on the elastic deformation $(10 \mathrm{~mm})$ of roofing of each horizon $\Delta 1$ incomplete filling of chambers about $1 \% \Delta_{2}$, and backfill compression due to load $\Delta_{3}=\varepsilon_{0} h_{H}$, and changes in vertical stress $\sigma_{1}$.

$$
\begin{aligned}
& \sigma_{1}=\mathrm{K} \alpha \mathrm{K}_{\mathrm{v}} \rho g \mathrm{H}_{\mathrm{s}} \\
& \Delta_{\mathrm{p}}{ }^{\prime}=\mathrm{H}_{\mathrm{sr}} / \mathrm{K}_{\mathrm{d}} \\
& \sigma_{\mathrm{z}}=\sigma_{1}{ }^{\prime} \cdot \ln \varepsilon_{\mathrm{o}} \cdot \mathrm{N}_{\mathrm{H}} \mathrm{h}_{\mathrm{H}} / \ln \Delta \mathrm{P}{ }^{\prime}
\end{aligned}
$$

Besides the well-known marks $\mathrm{K}_{\mathrm{v}}$ coefficient which takes the stress change in the fill, depending on the ratio of ore body width and the depth of deposit $K_{v}=\left(A_{R} / H_{s}\right)+0.61 ; A_{R^{-}}$size of ore body by stretching or declining.
From this formula it is evident that protection of the earth's surface from deformation besides strength of backfill, its compressibility is an important parameter, because the strength of backfill on pressure may be less than the vertical stress. Pri $\Delta \mathrm{P}^{\prime}=\varepsilon_{0} \mathrm{~N}_{\mathrm{h}} \mathrm{h}_{\mathrm{H}} ; \sigma_{\mathrm{z}}=\sigma^{\prime}$.

\section{CONCLUSION}

For the known geometry of layer, physical and mechanical properties of deposit rocks and accompanying rocks of roofing and bottom, and objectives to be achieved, using the chamber pillar mining method with storage of ore and filling the excavated chambers after discharge of ore, curing backfill, in order to obtain the remaining protective pillars from backfill, according to Fig. 3. It is possible on the basis of considered mutual work of deposit rocks and backfill, in chambers filled, to choose the best dynamics of deposit excavation, arrangement of excavation, backfill material of adequate strength and compressibility, etc.

\section{REFERENCES}

[1] D. M. Broninkov et al., Backfill Works in the Mines Nedra, Moscow, Russia 1989, p. 146, (In Russian);

[2] V. I. Homyakov, Foreign Experience Tab in the Mines Nedra, Moscow, Russia, 1984, p. 143, (In Russian);

[3] V. R. Imenitov, V. F. Abramov, V. V. Popov, Localization of Emptiness in the Underground Ore Mining, Nedra, Moscow, Russin, 1983, p. 72, (In Russian);

[4] M. Miljković, R. Stanojlović, J. Sokolović, Safety and Deformation Characteristics of Stopping Materials in Mines, Mining Engineering, Bor, 2(2012), pp. 13-28;

[5] V. Jovičić, M. Miljković, J. Nujić, H. Uljić, M. Vukić, Security Systems in Mining Industry, Tuzla, Univerzal, 1987, p. 423. 


\begin{tabular}{ll}
\hline \hline INSTITUT ZA RUDARSTVO I METALURGIJU BOR & ISSN: 2334-8836 (Štampano izdanje) \\
UDK: 622 & ISSN: 2406-1395 (Online) \\
\hline \hline
\end{tabular}

UDK: $622.261: 581.5(045)=163.41$

DOI:10.5937/MMEB1502053M

Miodrag Miljković, Rodoljub Stanojlović, Jovica Sokolović*

\title{
ODREĐIVANJE POTREBNE ČVRSTOĆE ZASIPA PRI POTPUNOM OTKOPAVANJU LEŽIŠTA ${ }^{* *}$
}

\begin{abstract}
Izvod
Osnovni ciljevi otkopavanja ležišta metodama sa zapunjavanjem otkopanih prostora su: povećanje ili potpuno iskorišćenje ležišta bez osiromašenja rude, otkopavanje ležišta u složenim rudarskogeološkim uslovima, očuvanje ekoloških faktora u životnoj okolini, poboljšanje ergonomsko sigurnosnih uslova rada i recirkulacija otpadne jalovine.

Za postizanje ovih ciljeva potrebno je u otkope ugrađivati zasipni materijal odgovarajućih fizičko mehaničkih karakteristika, a posebno u pogledu čvrstoće na pritisak. U radu je razmatran postupak izbora zasipnog materijala potrebne čvrstoće pri primeni otkopnih metoda sa zapunjavanjem otkopnih prostora pri potpunom dobijanju ležišta i zaštiti zemljine površine i objekata od oštećenja.

Ključne reči: potpuno otkopavanje ležišta, zapunjavanje otkopa, čvrstoća zasipa
\end{abstract}

\section{UVOD}

Potpuno otkopavanje ležišta mineralne sirovine bez osiromašenja rude uz očuvanje ekoloških faktora u eksploatacionom polju može da se realizuje samo otkopnim metodama sa zapunjavanjem otkopanih prostora u uzlaznom ili silaznom poretku otkopavanja i zapunjavanja [1]. Zavisno od ciljeva potpunog otkopavanja ležišta sa zapunjavanjem otkopanih prostora, određuje se potrebna čvrstoća zasipa i bira se vrsta zasipnog materijala kojim se ta čvrstoća može postići [2]. Čvrstoća zasipa naziva se normativnom ako je moguće njime obezbediti sigurno držanje potrebnih

otvorenih prostora. To se može postići primenom očvršćavajućeg zasipa [3].

Potpuno dobijanje ležišta bez osiromašenja rude može se realizovati sledećim grupama otkopnih metoda [4]:

1. Etažno otkopavanje hodnicima, strmih rudnih žica i sočiva; a) odozdo na gore, stajanjem opreme na zasipu, b) odozgo na dole, ispod zasipa, kada oprema stoji na čvrstoj steni (rudi).

2. Jednoslojno ili višeslojno otkopavanje moćnih rudnih ležišta; a) vertikalno slojno otkopavanje odozdo na gore, (oprema se kreće po zasipu), b) horizontalno slojno

\footnotetext{
* Univerzitet u Beogradu, Tehnički fakultet u Boru, Vojske Jugoslavije 12, 19210 Bor, Srbija, **-mail: jsokolovic@tf.bor.ac.rs
}

im proizvodnim sistemima Rudnik bakra Bor i Rudnika bakra Majdanpek" i TR 33038 "Usavršavanje tehnologije eksploatacije i prerade rude bakra sa monitoringom životnog i radnog okruženja u RTB Bor Grupi", koje je finansiralo Ministarstvo za obrazovanje, nauku i tehnološki razvoj Republike Srbije. Autori se zahvaljuju Ministarstvu za finansijsku podršku. 
otkopavanje odozgo na dole, ispod betonske ploče (oprema se kreće po čvrstom podu).

3. Podetažno otkopavanje ležišta sa naknadnim zapunjavanjem otkopa; a) očvršćavajućim zasipom sa kretanjem otkopnog fronta odozdo na gore, b) ispod betonske ploče, sa zapunjavanjem otkopa očvršćavajućim zasipom (kretanjem otkopnog fronta odozgo na dole.

4. Komorno stubno otkopavanje ležišta sa magazioniranjem rude, zapunjavanjem otkopa po istakanju rude očvršćavajućim zasipom i naknadnim dobijanjem zaštitnih stubova rude $\mathrm{u}$ zasipu istom otkopnom metodom. Tu se može primeniti: a) panelno i b) unakrsno otkopavanje komora.

U zavisnosti od poretka otkopavanja, konstrukcije i geometrije otkopa, ciljeva, troškova primene otkopne metode, fizičkomehaničkih karakteristika ležišta i pratećih stena, kao i dubine ležišta, vrši se određivanje potrebne čvrstoće zasipa.

\section{ODNOSI PRATEĆIH STENA LEŽIŠTA I ZAPUNJENIH OTKOPANIH PROSTORA U LEŽIŠTU}

Čvrstoća stvrdnjavajućeg zasipa je zadovoljavajuća (normativna) ako je moguće sigurno otvaranje veštačkog, (zasipnog), masiva projektovanim rudničkim prostorijama i otkopima, i ako obezbeđuje očuvanje zemljine površine i objekata iznad ležišta od deformacija. Na masiv od zasipnog materijala deluju gravitacione i tektonske (statičke) i od minerskih radova (dinamičke) sile. Masa zapunjenog otkopa može biti podvrgnuta deformacijama usled pritiska, rastezanja, smicanja, izuvijanja u uslovima jednoosnog, dvoosnog i zapreminskog napregnutog stanja. Za izbor i kontrolu potrebne čvrstoće zasipnog materijala, s obzirom na uloge koje treba da zadovolji, nezavisno od karaktera opterećenja, čvrstoća zasipnog materijala bira se prema potrebnoj čvrstoći na jednoosni pritisak.
Potrebna čvrstoća zasipnog materijala određuje se po jednom ili više faktora:

a) stabilnosti (držanja) vertikalnih otvorenih bokova

b) horizontalno otvorenih plafona,

c) dopuštenih deformacija zemljine površine,

d) mogućnosti kretanja opreme po površini zasipa itd.

Masa od zasipnog materijala i okolne stene, u određenim uslovima obrazuju složeni prostorni sistem zasip - stene. Glavni strukturni elementi takvog sistema - stene krovine i podine i zasipnog prostora, veoma se razlikuju.

Proračun potrebne čvrstoće zasipa bazira se na znanjima o naponsko - deformacionim karakteristikama prirodnog stenskog i veštačkog, (od zasipa), masiva u zoni otkopavanja, karaktera njihovog uzajamnog delovanja i svodi se na rešavanje triju zadataka.

1. Nalaženja opterećenja na masu zasipanog otkopa

2. Određivanja napona u zasipu kao sastavnom elementu sistema stene, (stena zasipani prostor).

3. Utvrđivanja neophodne čvrstoće zasipa, koja proističe iz potrebnog koeficijenta pokazanosti, (sigurnosti), za određeno naponsko stanje, uz uticaj ostalih tehnoloških faktora pri otkopavanju ležišta.

Opterećenje na veštački masiv zasipa u otkopu zavisi: od fizičko-mehaničkih karakteristika okolnih stena, napona u njima, geometrije zapunjenog otkopa, (veličine, dubine i nagiba), i fizičko-mehaničkih karakteristika zasipa, kao i od uloge koju konstrukcija od zasipnog materijala ispunjava u toku dalje eksploatacije i po završetku eksploatacije ležišta.

Pri potpunom otkopavanju ležišta (otkop uz predhodni zapunjeni otkop), u krovini ležišta, u blizini otkopa, obrazuje se zona smanjenog pritiska (rasterećenja), a u rudnom masivu ispred fronta napredovanja 
otkopa pojavljuje se zona povišenog oslonačkog pritiska sl. 1. Sa povećanjem širine otkopanog prostora i zapunjenog prostora, stene krovine i zasip u zapunjenom prostoru ponašaju se kao okolne stene i popustljiva podgrada, dok zasip ne primi celokupno opterećenje stuba krovinskih stena. Opterećenje na otkopu potiče od ploče stena krovine, koja se jednim delom oslanja na zasipani deo otkopa, a drugim delom na rudni masiv. Dimenzije zone rasterećenja su proporcionalne deformacionim karakteristikama zasipa $\varepsilon$. Deformaciona karakteristika zasipa zavisi od vrste zasipa i načina ugradnje. Pri $\varepsilon \leq 3 \%$ pomeranje nalegajućih stena vrši se povijanjem bez pucanja i komadanja. Pri $\varepsilon \geq 3 \%$ u krovini dolazi do pucanja i raslojavanja stena.

Vrednost koeficijenta koncentracije napona $\mathrm{u}$ rudnom masivu određuje se na osnovu širine otkopanog prostora L i koncentracije napona $\mathrm{u}$ rudnom masivu, po obrascima:

$$
\begin{aligned}
& \mathrm{K}_{\mathrm{k}}=2,1-1,1 e^{-(L / 80)^{1,5}} \\
& \mathrm{~K}_{\mathrm{k}}=\left(0,8 \mathrm{l}_{\mathrm{e}} \cdot \mathrm{n}+14\right) \mathrm{H}^{-0,33}
\end{aligned}
$$

gde su:

e - osnova prirodnog logaritma

$\mathrm{L}$ - širina otkopanog prostora $\mathrm{m}, \mathrm{L}=\mathrm{n} \cdot \mathrm{l}_{\mathrm{e}}$

$1_{\mathrm{e}}$ - širina otkopa (trake, sloja) u dobijanju (ekvivalentna stubna širina plafona otkopa)

$\mathrm{n}$ - broj traka u jednovremenom dobijanju do postizanja kritične širine $\mathrm{l}_{\mathrm{k}}=\mathrm{n} \cdot \mathrm{l}_{\mathrm{e}}$

$\mathrm{H}$ - dubina izvođenja radova za koju su vezani naponi u krovu;

$$
\tau=\rho g \mathrm{H},(\mathrm{Pa})
$$

Ispitivanja su pokazala da maksimalni oslonački pritisak, pri širini otkopnog prostora $\mathrm{L}=30-40 \mathrm{~m}$ iznosi $(1,5-1,6) \rho g \mathrm{H}$. Maksimum se nalazi na $15-20 \mathrm{~m}$ od čela otkopnog fronta, a širina opterećene zone iznosi oko $50 \mathrm{~m}$. Zasipni materijal trpi opterećenje tek pri širini otkopanog prostora 40 $60 \mathrm{~m}$.
Pri otkopavanju ležišta ispod zasipa, zasipni materijal igra ulogu veštačke krovine, ispod koje se takođe obrazuje zona rasterećenja u zoni otkopa i zone oslonačkog pritiska na bokove ispred čela otkopnog fronta i u zapunjenom prostoru. Opterećenje zavisi od sopstvene težine zasipa i pritisku krovinskih stena, ako su već pretrpele deformacije.

\section{POTREBNA ČVRSTOĆA ZASIPA PRI OTKOPAVANJU KOMORA ZA ZAPUNJAVANJEM}

Ekonomično otkopavanje masivnih siromašnih (niske vrednosti) rudnih ležišta primenom otkopnih metoda sa zapunjavanjem otkopanih prostora, može da se izvrši samo primenom visoko produktivnih otkopnih metoda. Jedna od njih može biti komorno stubna otkopna metoda sa magazioniranjem rude, zapunjavanjem komora po istakanju rude očvršćavajućim zasipom i naknadnim dobijanjem zaštitnih stubova rude istom otkopnom metodom, za koju treba izvršiti analizu potrebne čvrstoće zasipa (sl. 2.).

Potrebna čvrstoća zasipa može se posmatrati za tri stadijuma u kojima se može naći stub od zasipnog materijala u otkopnom prostoru.

1. Kada se komora nalazi izmeđut zaštitnih stubova od rude (I stadijum).

2. Kada se komora nalazi između stuba od rude i stuba očvrslog zasipa susedne otkopane komore (II stadijum) ili zapunjenog prostora.

3. Kada se komora nalazi između zaštitnih stubova od očvrslog zasipa.

1. U prvom stadijumu zasip u komori neće biti opterećen nikakvim vertikalnim opterećenjem više ležećih stena, osim sopstvenom masom. Bočno opterećenje u stubu zasipa može se pojaviti usled deformacija bokova komore. Stabilni raspon plafona komore $\left(l_{e}\right)$ određuje se iz strogih uslova stabilnosti rudničkih prostorija i otkopa, odnosno plafona komora. 
Stabilnost potkopanog plafona prema ktiričnim deformacijama određuje se iz uslova.

$$
\mathrm{g}_{\mathrm{r}}>\mathrm{g}_{\mathrm{d}}
$$

gde su:

$\mathrm{g}_{\mathrm{d}}$ - dopuštena deformacija plafona, pri kojoj je plafon komore stabilan.

$\mathrm{g}_{\mathrm{r}}$ - relativna deformacija plafona komore. Ona se određuje po formuli:

$\mathrm{g}_{\mathrm{r}}=1 /\left[1+\left(\mathrm{H}_{\mathrm{R}} / \mathrm{le}\right)^{\mathrm{f}}\right]$

$\mathrm{H}_{\mathrm{R}}$ - redukovana za uslove monolitnog masiva, dubina plafona komore

$\mathrm{H}_{\mathrm{R}}=\left(1-\mathrm{K}_{\mathrm{g}}\right) \mathrm{H}_{\mathrm{k}}$

$\mathrm{H}_{\mathrm{k}}$ - debljina krovine od nanosa na površini do ravni plafona komore

$\mathrm{K}_{\mathrm{g}}$ - koeficijent gubitka stabilnosti plafona zbog raspucalosti i strukturnih osobina stena (zavisno od RQD karakteristike). Njegova vrednost može biti određena na osnovu procenta izvađenog jezgra

$\mathrm{K}_{\mathrm{g}}=0,84+0,01 \mathrm{Nj}-0,0002 \mathrm{Nj}^{2}$ gde su:

$\mathrm{Nj}$ - procenat izvađenog jezgra (često se prikazuje visoka vrednost)

f - koeficijent čvrstoće stena po Protodjakonovu $1_{e}$ - ekvivalentni stabilni raspon šupljine (širine) komore

Ekvivalentni stabilni raspon (širina) komore može biti određen, ako se usvoje granični uslovi, i formula reši eksplicitno po $1_{\mathrm{e}}$.

$\mathrm{g}<0,001-$ stabilni raspon komore

$\mathrm{g}=(0,001-0,04)$ - stanje između stabilnosti i potpunog zarušavanja

$\mathrm{g} \leq 0,04$ - potpuno obrušavanje nalegajuće krovine

$$
l_{e}=\sqrt[f]{\frac{g H_{R}^{f}}{1-g}}=H_{R} f \sqrt{\frac{g}{1-g}}, \quad(\mathrm{~m})
$$

Naponi će se koncentrisati u bokovima komore prema sl. 1.

Oni se neće prenositi na zasip u komori, ili čak i više komora, dok šupljina ispod podkopane krovine ne dostigne kritičan raspon (govori se o šupljini jer se pri zapunjavanju otkopa nikad neće potpuno poduhvatiti krovina).

$$
\mathrm{l}_{\mathrm{k}}=\mathrm{H}_{\mathrm{k}} \sqrt[f]{\frac{g}{1-g}},(\mathrm{~m})
$$

pri $g>0,04$

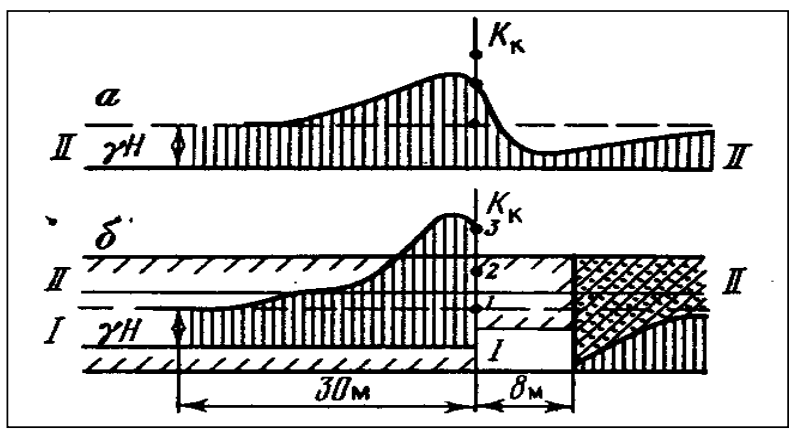

Sl. 1. Grafik promene koncentracije napona u rudnom i masivu od zasipa

2. Drugi stadijum položaja komora u otkopavanju i zapunjenog prostora je najčešći. Pri eksploataciji velikih strmih rudnih tela, kritični raspon otkopanog prostora pri kome dolazi do zarušavanja kro- vine, manji je od dužine otkopnog fronta Zarušeni blokovi stena opterećivaće zapunjeni prostor. Ako je zasip stišljiv (plastičan) doći će do većih deformacija u krovini, pa čak i do deformacija zemljine povr- 
šine (kod plićih ležišta). Ipak zapunjeni prostor predstavlja zonu rasterećenja. Pri kretanju otkopnog fronta od periferije rudnog tela, prema prostorijama otvaranja, mogu se prijaviti sledeći slučajevi rasporeda napona:

a) Iznad prvih otkopanih komora pri širini otkopanog prostora $\mathrm{L}=\mathrm{nl}_{\mathrm{e}}<\mathrm{l}_{\mathrm{k}}$ (stabilne ekvivalentne širine) u krovini otkopa pojavljuju se zatezni naponi, a nabokovima otkopa i neporemećenih stena koncentrišu se naponi pritiska, zavisno od širine otkopanog prostora. Koeficijent koncentracije napona određuje se po formuli za $K_{k}$, pa vertikalni napon u masivu iznosi:

$$
\sigma_{\mathrm{p}}=\mathrm{K}_{\mathrm{k}} \rho_{\mathrm{s}} \mathrm{gH}, \quad(\mathrm{Pa})
$$

Horizontalni napon $\sigma_{\mathrm{y}}$ na boku komore prema slici 2. iznosi:

$$
\sigma_{y}=\frac{\mu}{1-\mu} K_{k} \rho_{s} g H,(\mathrm{~Pa})
$$

gde je:

$\mu$ - koeficijent Pausona $\mu=(0,4 \div 0,6)$
(koeficijent bočnog opterećenja)

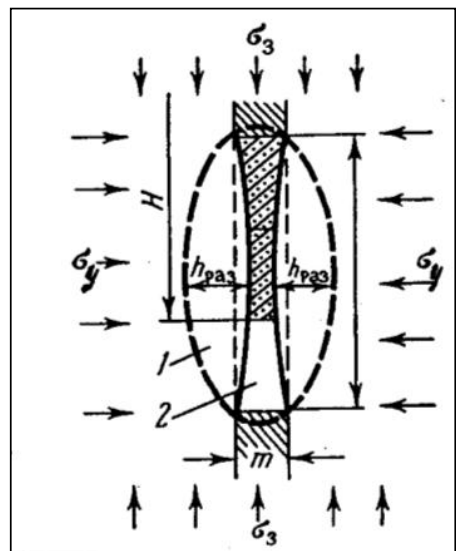

Sl. 2. Šema za proračun napona iz zaštitnih stubova na zasip u komori

Koeficijent koncentracije napona kako ispred čela otkopnog fronta $\mathrm{u}$ rudniku, tako i u krajnjim stubovima od zasipa povećavaće se sa otkopavanjem svake naredne komore, dok raspon otkopanog prostora ne pređe kritičnu širinu $L>1_{k}$.

b) Kada bude otkopano više komora, tako da raspon otkopanog prostora L postane nestabilan ili se zaruši, doći će do pojave vertikalnog napona i u masivu od zasipa. Veličina vertikalnog napona koji se može pojaviti u veštačkim stubovima od zasipa proračunava se koristeći princip istovremene deformacije kombinovanih oslonaca, stubova od rude i stubova zasipa po formuli:

$$
\sigma_{1}=\frac{K_{a} \rho_{s} g H S_{k}}{10^{6}\left(S_{z}+0,77 S_{p} \frac{E_{s}}{E_{z}}\right)}+10^{-6} \rho_{z} g h_{z}
$$

gde su:

$\rho_{\mathrm{s}} ; \rho_{\mathrm{z}}$ - gustine stenskog materijala i zasipnog materijala

$\mathrm{H}$ - dubina plafona otkopanog prostora

$\mathrm{Sk}$; Sz - površine stubova rude i stubova od zasipa

Es; Ez - moduli deformacije stena rudnog ležišta i zasipnog materijala

$\mathrm{K}_{\mathrm{a}}$ - koeficijent uticaja ugla nagiba ležišta na opterećenje zasipa

$\mathrm{K}_{\mathrm{a}}=\cos ^{2} \alpha-\eta \sin ^{2} \alpha ; \eta=\mu /(1-\mu)$

$\mathrm{h}_{\mathrm{z}}$ - visina stuba od zasipa (visina otkopanog i zapunjenog prostora)

$\alpha$ - ugao nagiba ležišta (nagib zapunjene šupljine). 
Čvrstoća zasipa u otkopanom prostoru mora biti veća od vertikalnog napona koji se pojavljuje u zasipu, da ne bi došlo do popuštanja i sabijanja zasipa i dalje deformacije krovine.

$$
\sigma_{\mathrm{z}}>\sigma_{1}
$$

Kod dubokih tankih ležišta može se dopustiti i sabijanje zasipa do određene visine, pri kojoj neće doći do nedopuštenih deformacija zemljine površine i smanjenja koeficijenta sigurnosti K [4].

c) Krajnji slučaj drugog stadijuma pojavljuje se pri kretanju otkopnog fronta tako da se dobijanje komora vrši između masiva rude i masiva zasipa. Krovina se oslanja na otkopni front rude, sa konzolom ne oslonjene krovine na zasip dužine $1<1$; $1<\mathrm{n} \cdot 1_{\mathrm{e}} \mathrm{i}$ dela krovine koji je popustio pod naponom višeležećih masa. Komora $u$ otkopavanju se nalazi u zoni ispod konzole, gde su vertikalni naponi smanjeni. Maksimalni vertikalni napon se nalazi ispred otkopnog fronta $\mathrm{u}$ rudnom masivu. I za komore $\mathrm{u}$ otkopavanju na rastojanju $1<1_{k}$ nalazi se zona smanjenog vertikalnog napona. $\mathrm{Na}$ rastojanju $\mathrm{L}>\mathrm{l}_{\mathrm{k}} \mathrm{i}$ masiv zasipa se nalazi pod koncentrisanim vertikalnim naponom istim kao u rudnom masivu.

Za iznalaženje potrebne čvrstoće zasipa za očuvanje zemljine površine od deformacija potrebno je uzeti u obzir moguće dopušteno sabijanje zasipa pri kome neće doći do oštećenja zemljine površine.

Za slepa izolovana ležišta pravilnog oblika, uticaj dimenzija (visine) otkopanog i zapunjenog područja na deformaciju (sleganje) zemljine površine $u$ zavisnosti od kompresionih svojstava zasipa ocenjuje se na osnovu koeficijenta sigurnosti, čija vrednost treba da bude veća od dopuštene prema tabeli 1 [5].

$$
\mathrm{Ks}>\mathrm{Kd}=\mathrm{H} / \Delta \mathrm{P}
$$

Vertikalna prihvatljiva veličina deformacije zasipanog prostora $\Delta \mathrm{P}$ određuje se po formuli:

$$
\Delta \mathrm{P}=\varepsilon_{\mathrm{o}} \mathrm{h}_{\mathrm{z}}(1-\mathrm{e}) \sigma_{1} / \sigma_{\mathrm{z}},(\mathrm{m})
$$

gde su:

$\Delta \mathrm{P}$ - smanjenje visine stuba od zasipa pod opterećenjem $\sigma_{1},(\mathrm{~m})$

$\sigma_{1}$ - dejstvojući vertikalni napon, $(\mathrm{Pa})$

$\varepsilon_{\mathrm{o}}$ - deformaciona karakteristika određene vrste zasipa

$\mathrm{h}_{\mathrm{z}}$ - debljina (visina) stuba zasipa

$\sigma_{\mathrm{z}}$ - čvrstoća zasipa na pritisak

$\mathrm{K}_{\mathrm{s}}$ - koeficijent sigurnosti kojim se ocenjuje stabilnost krovine

Iz prethodne formule može se izračunati potrebna ili dovoljna čvrstoća zasipa $\sigma_{\mathrm{z}}$ za tanka duboka ležišta, kod kojih će usled opterećenja krovine zasip biti preopterećen i delimično sabijen. Dopušteno sabijanje zasipa biće $\Delta \mathrm{P}=\mathrm{H} / \mathrm{Kd}$, a potrebna čvrstoća zasipa $\sigma_{\mathrm{z}}$ :

$$
\sigma_{z}=\frac{\sigma_{1} \ln \cdot \varepsilon_{o} h_{z}}{\ln (\Delta P)},(\mathrm{Pa})
$$

3. Stadijum kada se vrši otkopavanje zaštitnog stuba ili komore koja se nalazi između zaštitnih stubova od očvrslog zasipa (u zasipu) je najopasniji, jer u stubovima dolazi do koncentracije napona sa obe strane iz otkopanih prostora. Naponi se sabiraju, a mogu se proračunati po formulama za $\sigma_{\mathrm{p}} \mathrm{i}$ $\sigma_{\mathrm{y}}$. U pripremnim prostorijama može doći do ispoljavanja dinamičkih pojava i gorskih udara. Do gorskih udara neće doći ako stena stuba nije sklona akumulaciji energije elastične deformacije i ako su koncentrisani naponi manji od čvrstoće stene na pritisak $\sigma_{\mathrm{p}}<\sigma_{\mathrm{cs}}$.

Do ispoljavanja gorskih udara neće doći i ako zasip u zapunjenom prostoru ima odogovarajuću pritisnu čvrstoću, tako da može da izvrši ukrućenje stuba rude i obezbedi stabilnost otkopne komore pri otkopavanju. Normativa pritisna čvrstoća zasipa u fazi dobijanja komora između stubova od zasipnog materijala treba da iznosi:

$$
\sigma_{z}=\frac{\sigma_{s} K_{z}}{K_{f} \cdot K_{o}}
$$


gde su:

$$
\begin{gathered}
\sigma_{\mathrm{s}}=\mathrm{K}_{\mathrm{a}} \mathrm{K}_{\mathrm{hp}} \mathrm{gH} \cdot \mathrm{L}_{\mathrm{s}} / 10^{6} \mathrm{~L}_{\mathrm{z}} \text { - napon u stubo- } \\
\text { vima zasipa } \\
\mathrm{K}_{\mathrm{z}} \text { - koeficijent sigunosti } \mathrm{K}_{\mathrm{z}}=(1,5-3)
\end{gathered}
$$

$\mathrm{K}_{\mathrm{f}}$ - koeficijent forme stuba. $\mathrm{S}$ obzirom na uticaj oblika dimenzija stuba na noseću sposobnost $\left[\mathrm{K}_{\mathrm{f}}=\left(\mathrm{a} / \mathrm{h}_{\mathrm{s}}\right)^{0,5}\right.$ pri $\left.a>h_{s}\right]$ ili $\left[K_{f}=0,6+0,4 a / h_{s}\right.$ pri a $\left.>h_{s}\right]$;

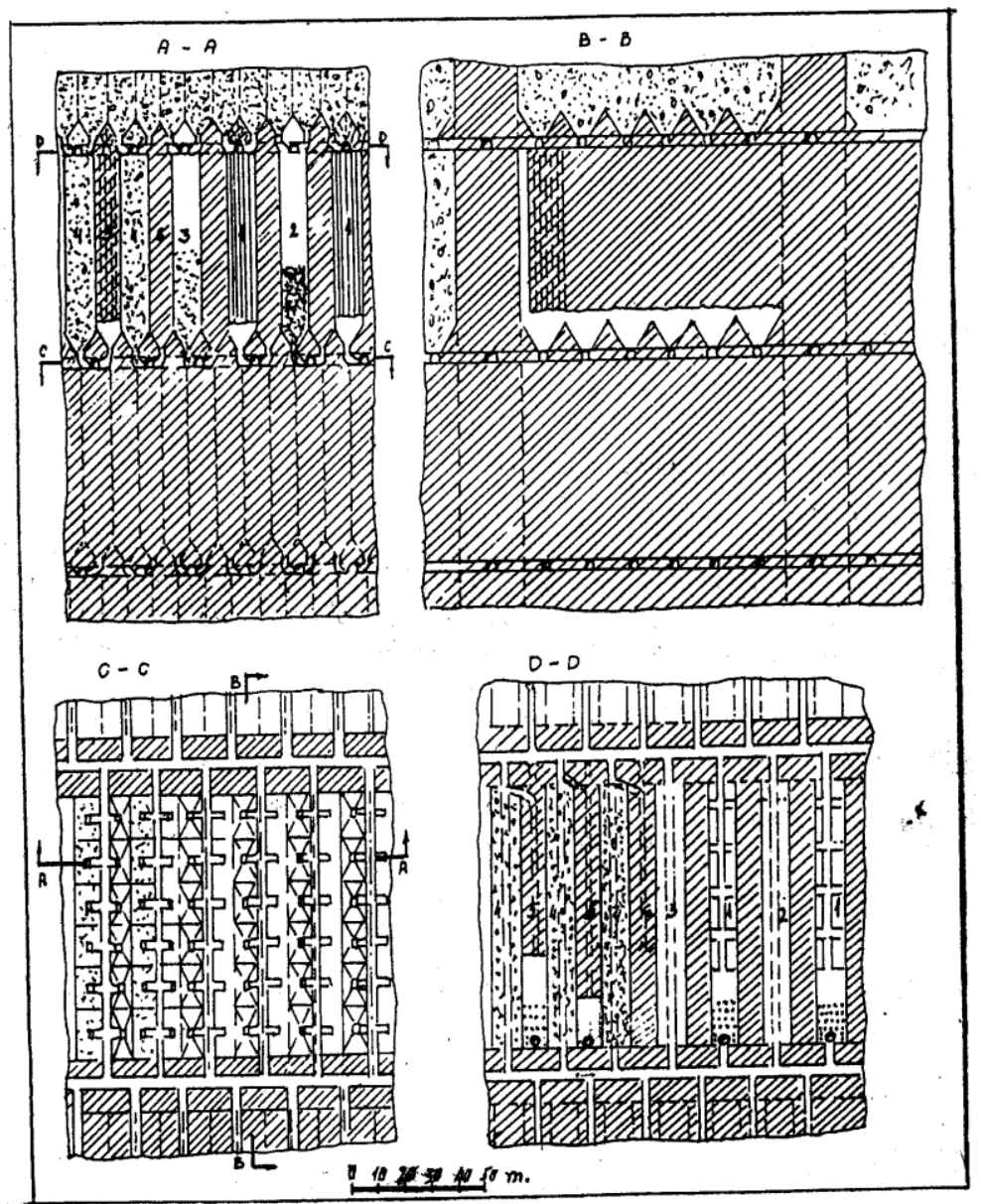

Sl. 3. Otkopavanje sa zapunjavanjem komora i naknadnim dobijanjem stubova

Tabela 1. Koeficijenti sigurnosti

\begin{tabular}{|c|c|c|c|}
\hline Kategorija objekata & \multirow{2}{*}{$\begin{array}{c}\text { Dopuštene horizontalne } \\
\text { deformacije }(\mathbf{m m} / \mathbf{m})\end{array}$} & \multicolumn{2}{|c|}{$\mathbf{K}_{\mathbf{d}}-$ za ležišta } \\
\cline { 3 - 4 } na prsini & 2,0 & Rudna & Ugljena \\
\hline I & 3,5 & 150 & 300 \\
\hline II & 5,5 & 100 & 200 \\
\hline III & \multicolumn{2}{|c}{} \\
\hline
\end{tabular}

a - širina stuba zasipa,

$\mathrm{h}_{\mathrm{s}}$ - visina stuba od očvršćavajućeg zasipa
$\mathrm{K}_{\mathrm{o}}$ - koeficijent kojim se uzima u obzir povećanje čvrstoće stubova na pritisak usled sabijanja; $\mathrm{K}_{\mathrm{o}}=\sigma_{\mathrm{k}} / \sigma_{\mathrm{o}}$ 
$\mathrm{H}$ - dubina gornje površine stuba

$\mathrm{K}_{\mathrm{h}}$ - koeficijent kojim se uzima u obzir stepen opterećenja stuba zasipa obrušenim stenama krovine

$\mathrm{L}_{\mathrm{p}}$ - širina panela bloka (komore) u zasipu

$\mathrm{L}_{\mathrm{z}}$ - širina panela veštačkih stubova od zasipa

Za neistražene "in situ" uslove $\mathrm{K}_{\mathrm{h}}=0,5$ $\frac{L}{H}<1$, a za komore između stubova od zasipa koje nisu zapunjenje $\mathrm{K}_{\mathrm{h}}=\mathrm{L} / \mathrm{h}<1$, gde je L - širina komore (potkopanog stuba).

Čvrstoća zasipnog materijala za obezbeđenje stabilnosti horizontalnih prostorija odnosno, projektovanih raspona prostorija u zasipu određuje se po formuli:

$$
\begin{aligned}
\sigma_{\mathrm{e}}= & \mathrm{K}_{\mathrm{z}}\left[0,49 \rho \mathrm{gH}_{\mathrm{z}} \cos \alpha\left(0,95-\mathrm{e}^{-, 06 \mathrm{a}}\right)-\right. \\
& 1,76] \mathrm{Pa}
\end{aligned}
$$

Izbor dimenzija komora i stubova i njihovog rasporeda pri otkopavanju, čvrstoće zasipa kod komorno stubne otkopne metode sa magazioniranjem rude i naknadnim zapunjavanjem odkopa očvršćavajućim zasipom, ako se otkopava više horizonata treba da se izvrši po formulama za $\Delta \mathrm{P}$ i $\sigma_{\mathrm{z}}=\mathrm{f}(\Delta \mathrm{P})$. U njima će doći do izmena vrednosti veličina. $\mathrm{H}_{\mathrm{z}}=\mathrm{Nh}_{\mathrm{H}} ; \mathrm{H}_{\mathrm{Z}^{-}}$visina zasipanog prostora zavisi od $\mathrm{N}$ visina otkopanih horizonata $h_{H}$. Dopuštena deformacija zasipnog prostora $\Delta \mathrm{P}^{\prime}=\left(\Delta_{1}+\Delta_{2}+\Delta_{3}\right) \mathrm{N}$ ne zavisi od elastične deformacije $(10 \mathrm{~mm}) \mathrm{kro}-$ vine svakog horizonta $\Delta 1$ nepotpunog zapunjavanja komora oko $1 \% \Delta_{2}$, i sabijanja zasipa usled opterećenja $\Delta_{3}=\varepsilon_{0} h_{H}$, kao i promene vertikalnog napona $\sigma_{1}$.

$$
\begin{aligned}
& \sigma_{1}=\mathrm{K} \alpha \mathrm{K}_{\mathrm{v}} \rho g \mathrm{H}_{\mathrm{s}} \\
& \Delta_{\mathrm{p}}{ }^{\prime}=\mathrm{H}_{\mathrm{sr}} / \mathrm{K}_{\mathrm{d}} \\
& \sigma_{\mathrm{z}}=\sigma_{1}{ }^{\prime} \cdot \ln \varepsilon_{\mathrm{o}} \cdot \mathrm{N}_{\mathrm{H}} \mathrm{h}_{\mathrm{H}} / \ln \Delta \mathrm{P},
\end{aligned}
$$

Pored poznatih oznaka $\mathrm{K}_{\mathrm{v}}$ - koeficijent kojim se uzima promena napona u zasipu u zavisnosti od odnosa širine rudnog tela $i$ dubine ležišta $K_{v}=\left(A_{R} / H_{s}\right)+0,61 ; A_{R}$-dimenzija rudnog tela po pružanju ili padu.
Iz ovih formula vidi se da je za zaštitu zemljine površine od deformacija pored čvrstoće zasipa, bitan parametar njegova stišljivost, jer čvrstoća zasipa na pritisak može biti i manja od vertikalnog napona. Pri $\Delta \mathrm{P}^{\prime}=\varepsilon_{\mathrm{O}} \mathrm{N}_{\mathrm{h}} \mathrm{h}_{\mathrm{H}} ; \sigma_{\mathrm{z}}=\sigma^{\prime}$.

\section{ZAKLJUČAK}

Za poznatu geometriju ležišta, fizičkomehaničke karakteristike stena ležišta i pratećih stena krovine i podine, kao i ciljeva koji se žele postići, primenom komorno stubne otkopne metode sa magazioniranjem rude i zapunjavanja otkopanih komora nakon istakanja rude, očvršćavajućim zasipom, u cilju dobijanja zaostalih zaštitnih stubova iz zasipa, prema slici 3 moguće je na osnovu razmotrenog uzajamnog rada stena ležišta i zasipa u zapunjenim komorama odabrati najpovoljniju dinamiku otkopavanja ležišta, raspored otkopa, zasipni materijal odgovarajuće čvrstoće i stišljivosti, itd.

\section{LITERATURA}

[1] D. M. Broninkov i sarad., Backfill works in the mines Nedra, Moscow, Russia 1989, p. 146. (In Russian)

[2] V. I. Homyakov, Foreign experience tab in the mines Nedra, Moscow, Russia, 1984, p. 143. (In Russian)

[3] V. R. Imenitov, V. F. Abramov, V. V. Popov, Localization of emptiness in the underground ore mining (In Russian), Nedra, Moscow, Russin, 1983, p. 72.

[4] M. Miljković, R. Stanojlović, J. Sokolović, Sigurnosne i deformacione karakteristike zasipnih materijala $\mathrm{u}$ rudnicima, Rudarski radovi, Bor, 2(2012), str. 13-28.

[5] V. Jovičić, M. Miljković, J. Nujić, H. Uljić, M. Vukić, Sigurnost i tehnička zaštita u rudarstvu, Tuzla, Univerzal, 1987, p. 423. 